\title{
Cultivation of oyster mushrooms (Pleurotus sp.) using organic waste: an example with Pleurotus pulmonarius (Fr.) Quel. \\ BIOOPEN 2021 - POST-CONFERENCE ARTICLE
}

\author{
LUIZA DAWIDOWICZ (1)
}

Poznan University of Life Sciences, Faculty of Agronomy, Horticulture and Bioengineering, Department of Vegetable Crops, Dąbrowskiego 159, 60-594 Poznan, Poland

E-mail: loocy7@op.pl

\begin{abstract}
Pleurotus pulmonarius (Fr.) Quel. is a mushroom species that occurs widely in nature on all continents except Antarctica. It is most common in North America. Its fruiting bodies are characterised by a mild taste and a slight anise aroma. These mushrooms are valued as a source of nutrients and substances with a healing effect. The anticancer, anti-inflammatory and antioxidant properties of $P$. pulmonarius have been scientifically proven, as well as its strong antihyperglycemic activity. $P$. pulmonarius is easy to grow because it has a very aggressive mycelium towards cellulosecontaining materials. In Poland, it can be grown on substrates based on cereal straw and various types of organic waste, including agricultural, horticultural, textile and forestry. In intensive crops, the substrates are also enriched with protein and carbohydrates. On an industrial scale, $P$. pulmonarius is grown primarily in Asia and North America on locally available organic materials.
\end{abstract}

KEYWORDS: edible and medicinal mushrooms, mushroom cultivation, substrate, supplementation, fruiting body

\section{Introduction}

Pleurotus pulmonarius (Fr.) Quel. (Figure 1) belongs to the kingdom Fungi, the phylum Basidiomycota, the class Agaricomycetes, the order Agaricales and the family Pleurotaceae. In the literature, it has been called 'boczniak płucny', its former Polish name, as well as 'lung oyster mushroom' and 'phoenix oyster mushroom' (Croan 2004, Jonathan et al. 2012). P. pulmonarius has a small hat, 5-20 cm in size, most often cream or

light brown in colour. It is shell shaped and paddle shaped - in younger specimens it is oyster-shaped - with a bent, sometimes ruffled edge. The gills have the colour of a hat, they are very dense and narrow and converge deeply to the stem, which is unremarkable. This species of oyster mushroom has a distinct stem, which grows on trees, reaching up to $6 \mathrm{~cm}$ in height and up to $1.5 \mathrm{~cm}$ in thickness. It is lateral, thinner towards the 


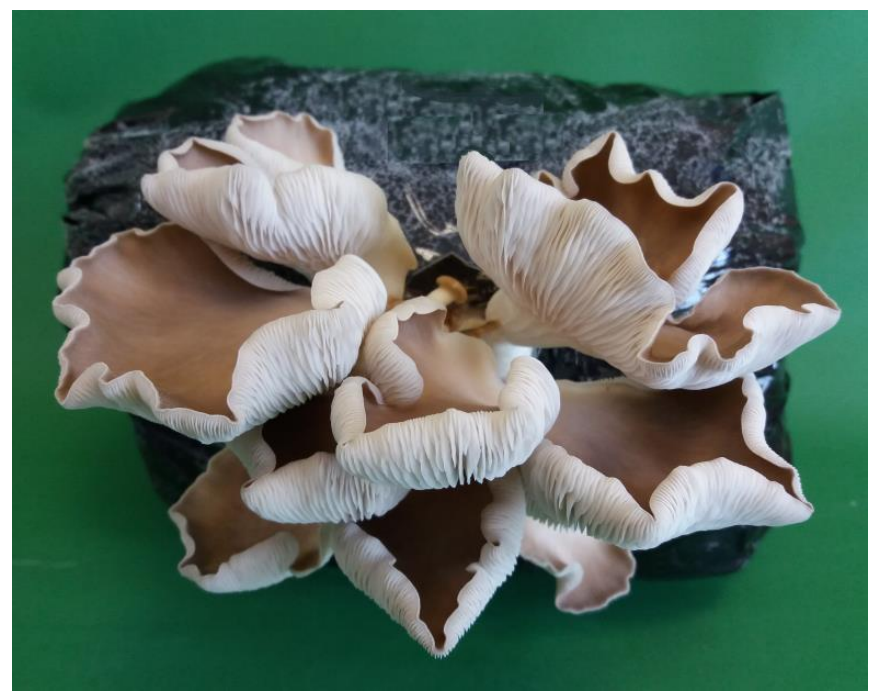

Figure 1. Fruiting bodies of Pleurotus pulmonarius.

base, whitish and felt. At first, the flesh is firm and juicy, hard and dry with age, with an imperceptible smell and sweet taste. The smell emitted by $P$. pulmonarius is indistinct and resembles anise, and its taste is slightly sweet and mild (Baggio et al. 2010; Janitor et al. 2007; Lechner et al. 2004; Škubla 2008).

In natural conditions, $P$. pulmonarius is found on all continents except Antarctica. It is most commonly found in North America. It is a species that grows in single specimens or in dense clumps of deciduous trees. It has also been observed on conifers. In the natural environment under Central European conditions, $P$. pulmonarius is found on dead trunks, logs and carps of trees such as beeches, oaks, birches, lindens, poplars and willows. It often occurs in the form of groups consisting of a dozen larger and smaller specimens that grow out of a common base or are arranged in a tile-like pattern on top of each other (Vilgalys et al. 1996; Janitor et al. 2007; Trudell and Ammirati 2009).

$P$. pulmonarius produces fruiting bodies during the warm season, from summer (June) to early autumn (October) (Škubla 2008). In Poland, it is a rare species and is included in the Red List of Plants and Mushrooms of Poland. It has the status of $\mathrm{V}$ - the species is at risk of extinction (Wojewoda and Lawrynowicz 2006).

P. pulmonarius may be confused with Pleurotus ostreatus (Jacq.) P. Kumm.; however, it has larger and thicker grayblue fruiting bodies, non-yellowing gills and appears only in late autumn. It can also be confused with Pleurotus dryinus (Pers.) P. Kumm., which produces larger fruiting bodies and grows mostly singly (Siwulski and Sobieralski 2004; Škubla 2008).

The aim of this work was to characterise $P$. pulmonarius and the methods of cultivating mushrooms from the genus Pleurotus.

\section{Nutritional value and healing properties of $\boldsymbol{P}$. pulmonarius}

$P$. pulmonarius is a tasty edible mushroom. In addition to its culinary value, its fruiting bodies have high nutritional value - they contain, among 
others, highly digestible proteins, fibre, vitamins and minerals, as well as biologically active substances with proven pro-health properties. The biological activity of these mushrooms has been confirmed in numerous laboratory and clinical tests, which have demonstrated, among others, their antibacterial, antiviral, antifungal, antitumor, immunomodulatory, antiallergic, anti-inflammatory, anti-atherosclerotic, hepatoprotective, blood sugar and cholesterol lowering effects. P. pulmonarius is low in calories due to the low content of lipids and starch. In many countries it is considered a healthy food (Manzi and Pizzoferrato 2000; Jose et al. 2002; Wasser 2002; Badole et al. 2006; Bernaś et al. 2006; Badole and Bodhankar 2007; Thekkut-tuparambil and Kainoor 2007; Smiderle et al. 2008; Akkanni et al. 2010; Lavi et al. 2010a, 2010b; Ramesh and Pattar 2010; Adebayo et al. 2012; Baggio et al. 2012; Olufemi et al. 2012; Patel et al. 2012; Smiderle et al. 2012; Xu et al. 2012).

\section{Cultivation of $\boldsymbol{P}$. pulmonarius}

In recent years there has been a very dynamic development regarding the production of edible and medicinal mushrooms around the world. This development has mainly been due to the high availability of inexpensive, often waste materials from agricultural production and the wood and textile industry, which can be a potential substrate for their cultivation. Poland, compared with the other European Union countries, is still an ecologically clean area. Therefore, it has enormous possibilities regarding the use of substrates not contaminated with heavy metals and pesticides for mushroom cultivation (Siwulski and Sobieralski 2004).

$P$. pulmonarius is the second most widely cultivated species in the world after P. ostreatus (Chiu et al. 1998).
These two oyster mushrooms are grown in a similar way and are most sold to consumers. $P$. pulmonarius was first found by an scientist in India and then brought to China, where its cultivation began. Recently, there has been an increase in the importance of its cultivation in Japan (Yatsuzuka et al. 2007). P. pulmonarius is especially popular in Western Europe, North America and New Zealand (Baggio et al. 2010). In Nigeria, it is one of the most consumed species (Onuoha et al. 2009).

$P$. pulmonarius is a saprotroph, a heterotrophic organism that obtains energy from the decomposition of organic compounds from the remains of dead higher organisms. Oyster mushrooms, thanks to their ability to decompose cellulose and lignin, cause white rot of wood. Therefore, they belong to the group of parasites living on trees (Gerhardt 2006, Trudell and Ammirati 2009).

$P$. pulmonarius is an easy-to-grow mushroom because it has a very aggressive mycelium towards materials containing lignin-cellulose. Researchers have shown that it can be grown on a variety of locally available waste such as: chopped cocoa pods, cotton waste, chopped corn straw, palm oil waste, tobacco straw, tea leaves, rice straw, sugar cane pomace, waste paper and sawdust (Banjo et al. 2004, Adebayo et al. 2009, Akinfemi and Ogunwale 2012). Adebayo et al. (2009) conducted research on the use of cotton waste substrate with the addition of cassava peel for the cultivation of P. pulmonarius. They showed that it can be used for mushroom cultivation if supplemented with a good source of nitrogen, such as urea or soybeans. Onuoha et al. (2009) used different substrates for the cultivation of $P$. pulmonarius. They found that sawdust was the best growth medium for this species, and the addition 
addition of cassava peel had a positive effect on the growth of the mushrooms.

Jonathan et al. (2012) showed that $P$. pulmonarius significantly supports the breakdown of lignin in agricultural waste (sorghum and rice straw stalks), a finding that is of great importance due to the possibility of using them as animal feed. Agricultural wastes are mostly fibrous and have low nutritional value due to the content of lignin, cellulose and hemicellulose, and the low levels of protein, soluble carbohydrates and minerals (Jonathan et al. 2010; Olusola and Anslem 2010). P. pulmonarius is able to bioconvert a wide variety of lignocellulosic materials by secreting extracellular enzymes (Jonathan et al. 2012). Silva et al. (2002) proved a similar effect of $P$. pulmonarius on waste from cotton cultivation, which can then be used as animal feed. Moreover, Valdez et al. (2008) confirmed the possibility of using agricultural waste from the cultivation of $P$. pulmonarius as feed for ruminants. This species, grown on wheat straw, changes its chemical composition and improves its nutritional value. Akinfemi and Ogunwale (2012) obtained similar results when cultivating $P$. pulmonarius on rice straw. The mushroom improved the digestibility of straw for ruminants and its nutritional value.

In Poland, oyster mushrooms are cultivated on 'hard straw' - wheat, triticale and rye, which, after preliminary preparation and inoculation with mycelium, are packed into bags made of perforated foil. In intensive, large-scale cultivation, the substrates are also enriched with protein and carbohydrates. This process utilises agricultural products such as chaff, bran, cereal grain, meal and oilseed cake, as well as other materials rich in nitrogenous substances and sugars (Figures 2 and 3) (Siwulski and Sobieralski 2004).

$P$. pulmonarius tolerates summer temperatures during mycelium growth and yielding. Fruiting bodies are formed at $10-20{ }^{\circ} \mathrm{C}$ and develop at $12-24{ }^{\circ} \mathrm{C}$. Light is an important factor that determines the yield and morphological features of oyster mushroom fruiting bodies. The best effects are obtained by using lighting with an intensity of 500

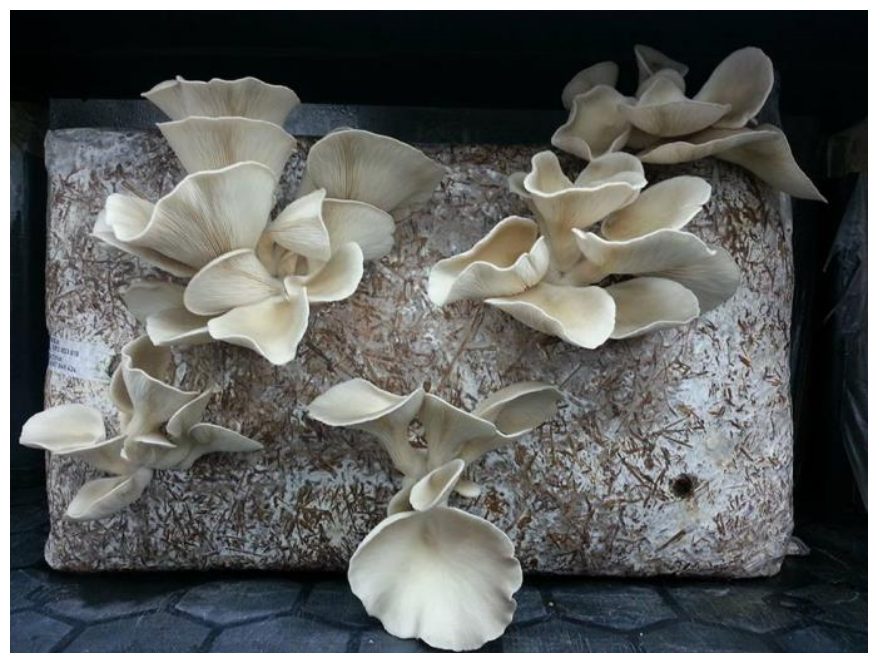

Figure 2. Fruiting bodies of Pleurotus pulmonarius in large-scale cultivation. 


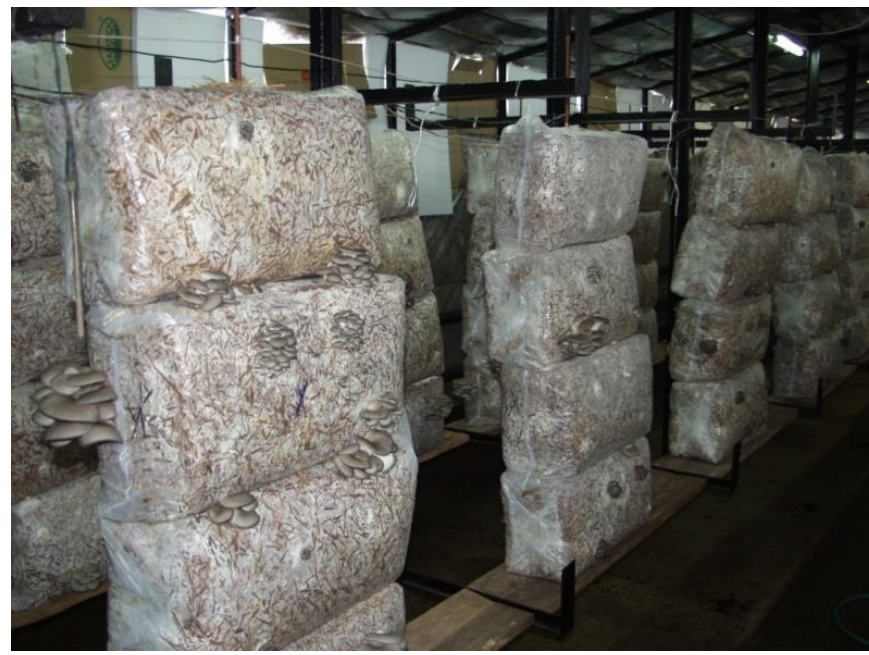

Figure 3. Large-scale cultivation of oyster mushrooms (from the genus Pleurotus) on a farm.

and $700 \mathrm{~lx}$ for $14 \mathrm{~h}$ a day (Siwulski and Sobieralski 2004; Siwulski et al. 2012).

Amateurs can also cultivate $P$. pulmonarius. This process is carried out under covers on the wood of practically all deciduous species and on sawdust from pine, spruce and fir trees, chopped straw and straw bales. Enrichment of substrates in amateur cultivation is not recommended. Substrates that are too rich in readily available nutrients are often attacked by moulds and bacteria that can inhibit or completely prevent the growth of the $P$. pulmonarius mycelium. The cultivation can also be carried out in open areas, in shady places (Siwulski and Sobieralski 2004; Siwulski et al. 2012).

\section{Summary}

$P$. pulmonarius is a species that requires careful evaluation. Currently, it is practically unknown in Poland and not cultivated on a large scale. $P$. pulmonarius can be an alternative to producers of other oyster mushroom species and at the same time diversify the market offerings of edible mushrooms because it can withstand high temperatures during mycelium growth and yielding. On the other hand, the management of waste in its production will significantly increase the profitability of cultivation and reduce its costs. Its cultivation will also provide a new way of using problematic waste. The development of a cheap and simple method for $P$. pulmonarius production in Poland may contribute to the introduction of this species to large-scale cultivation. Understanding the dependence of morphological and qualitative characteristics on the type of substrate and growing conditions will allow for the optimisation of production to obtain high-quality fruiting bodies, which will be suitable for human consumption and which could be used as raw material to obtaining biologically active substances.

\section{References}

Adebayo, E., Oloke, J., Ayandele, A., Adegunlola, C., 2012. Phytochemical, antioxidant and antimicrobial assay of mushroom metabolite from Pleurotus pulmonarius. Journal of Microbiology and Biotechnology Resources, 2(2): 366-374.

Adebayo, G., Omolara, B., Toyin, A., 2009. Evaluation of yield of oyster mushroom (P. pulmonarius) grown on cotton waste and 
cassava peel. African Journal of Biotechnology 8(2): 215-218.

Akinfemi, A., Ogunwale, O., 2012. Chemical composition and in vitro digestibility of rice straw treated with Pleurotus ostreatus, Pleurotus pulmonarius and Pleurotus tuberregium. Slovak Journal of Animal Science, 45(1): 14-20.

Akkanni, E., Oloke, J., Mabayoje, V., Saka, G. 2010. Clastogenicity potential screening of Pleurotus pulmonarius and Pleurotus ostreatus metabolites as potential anticancer and antileukaemic agents using micronucleus assay. British Journal of Pharmacology and Toxicology 1(2): 56-61.

Badole, S., Bodhankar, S., 2007. Interaction of aqueous extract of P. pulmonarius (Fr.) Quelchamp. with acarbose in alloxan induced diabetic mice. Journal of Applied Biomedicine, 5: 157-166.

Badole, S., Shah, S., Patel, N., Thakurdesai, P., Bodhankar, S., 2006. Hypoglycemic activity of aqueous extract of Pleurotus pulmonarius in alloxan-induced diabetic mice. Pharmaceutical Biology, 44(6): 421-425.

Baggio, C., Freitas, C., Marcon, R., de Paula Werner, M., Rae, G., Smiderle, F., Sassaki, G., Iacomini, M., Marques, M., Santos, A., 2012. Antinociception of $\beta$-d-glucan from Pleurotus pulmonarius is possibly related to protein kinase $\mathrm{C}$ inhibition. Pharmaceutical Biology, 44(6): 421-425.

Baggio, C., Freitas, C., Martins, D., Mazzardo, L., Smiderle, F., Sassaki, G., Iacomini, M., Marques, M., Santos, A., 2010. Antinociceptive effects of $(1 \rightarrow 3),(1 \rightarrow 6)$-linked $\beta$-glucan isolated from Pleurotus pulmonarius in models of acute and neuropathic pain in mice: evidence for a role for glutamatergic receptors and cytokine pathways. The Journal of Pain, 11: 965-971.

Banjo, N., Abikoye, E., Kukoye, A., 2004. Comparison of Tyree nutrient supplements used as additive to sawdust during the cultivation of oyster mushroom (Pleurotus pulmonarius). Nigerian Journal of Microbiology, 18: 335-336.

Bernaś, E., Jaworska, G., Lisiewska, Z., 2006. Edible mushrooms as a source of valuable nutritive constituents. Acta Scientiarum Polonorum, Technologia Alimentaria, 5(1): 5-20.

Croan, S., 2004. Conversion of conifer waste into edible and medicinal mushrooms. Forest Products Journal, 54(2): 68-76.

Chiu, S., Chan, Y., Law, S., Cheung, K., Moore, D., 1998. Cadmium and manganese in contrast to calcium reduce yield and nutritional values of the edible mushroom Pleurotus pulmonarius. Mycological Research, 102(4): 449-457.

Janitor, A., Kabát, V., Magál, J., Škubla, P., 2007. Atlas grzybów. Publicat, Poznań, 134.

Jonathan, S., Akinfemi, A., Adenipekun, C., 2010. Biodegradation and invitro digestibility of maize husks treated with edible fungi (Pleurotus tuber-regium and Lentinus subnudus) from Nigeria. Journal of Environmental, Agricultural and Food Chemistry, 9(4): 742-750.

Jonathan, S., Okorie, A., Garuba, E., Babayemi, O., 2012. Bioconversion of sorghum stalk and rice straw into value added ruminant feed using Pleurotus pulmonarius. Nature and Science, 10(4): 10-16.

Jose, N., Thekkuttuparambil, A., Kainoor, J., 2002. Antioxidant, anti-inflammatory and antitumoractivities of culinary medicinal mushroom Pleurotus pulmonarius (Fr.) Quel. (Agaricomycetideae). International Journal of Medicinal Mushrooms, 4(4): 329-335.

Lavi, I., Levinson, D., Peri, I., Nimri, L., Hadar, Y., Schwartz, B., 2010a. Orally administered glucans from the edible mushroom Pleurotus pulmonarius reduce acute inflammation in dextran sulfate sodium-induced experimental colitis. British Journal of Nutrition, 103(03): 393-402.

Lavi, I., Levinson, D., Peri, I., Tekoah, Y., Hadar, Y., Schwartz, B., 2010b. Chemical characterization, antiproliferative and antiadhesive properties of polysaccharides extracted from Pleurotus pulmonarius mycelium and fruiting bodies. Applied Microbiology and Biotechnology, 85(6): 1977-1990.

Lechner, B., Wright, J., Albertó, E., 2004. The genus Pleurotus in Argentina. Mycologia, 96(4): 845-858.

Manzi, P., Pizzoferrato, L., 2000. Beta-glucans in edible mushrooms. Food Chemistry, 68(3): 315-318.

Olufemi, A., Terry, A., Kola, O., 2012. Antileukemic and immunomodulatory effects of fungal metabolites of Pleurotus pulmonarius and Pleurotus ostreatus on benzene-induced leukemia in Wister rats. The Korean Journal of Hematology, 47(1): 67-73.

Olusola, S., Anslem, E., 2010. Bioremediation of a crude oil with Pleurotus pulmonarius and Glomus mosseae Rusing Amaranthus hybridus as a test plant. Journal of Bioremediation and Biodegradation, 1(3): 1-6.

Onuoha, C., Uchechi, U., Onuoha, B., 2009. Cultivation of Pleurotus pulmonarius (Mushroom) Using Some Agrowaste Materials. Agricultural Journal, 4(2), 109-112. 
Patel, Y., Naraian, R., Singh, V., 2012. Medicinal properties of Pleurotus species (oyster mushroom): a review. World Journal of Fungal and Plant Biology, 3(1): 1-12.

Ramesh, C., Pattar, M., 2010. Antimicrobial properties, antioxidant activity and bioactive compounds from six wild edible mushrooms of western ghats of Karnataka, India. Pharmacognosy Research, 2(2): 107-112.

Silva, S., Gomes da Costa, S., Clemente, E., 2002. Chemical composition of P. pulmonarius (Fr.) Quél., substrates and residue after cultivation. Brazilian Archives of Biology and Technology, 45(4): 531-535.

Siwulski, M., Sobieralski, K. 2004. Uprawa grzybów jadalnych i leczniczych w warunkach naturalnych. Kurpisz, Poznań, 158.

Siwulski, M., Ziombra, M., Sobieralski, K., 2012. Impact of light on fielding of some Pleurotus sp. strains. Acta Mycologica, 47(1): 65-73.

Škubla, P., 2008. Wielki atlas grzybów. Elipsa Public, Poznań, 432.

Smiderle, F., Olsen, L., Carbonero, E., Baggio, C., Freitas, C., Marcon, R., Santos, A., Gorin, P., Iacomini, M., 2008. Anti-inflammatory and analgesic properties in a rodent model of a $(1 \rightarrow 3),(1 \rightarrow 6)$-linked $\beta$-glucan isolated from Pleurotus pulmonarius. European Journal of Pharmacology, 597(1-3): 86-91.

Smiderle, F., Olsen, L., Ruthes, A., Czelusniak, P., Santana-Filho, A., Sassaki, G., Gorin, P., Iacomini, M., Exopolysaccharides, proteins and lipids in Pleurotus pulmonarius submerged culture using different carbon sources. Carbohydrate Polymers, 87(1): 368-376.

Thekkuttuparambil, A., Kainoor, K., 2007. Indian medicinal mushrooms as a source of antioxidant and antitumoragents. Journal of Clinical Biochemistry and Nutrition, 40(3): 157-162.
Trudell, S., Ammirati, J., 2009. Mushrooms of the Pacific Northwest. Timber Press Field Guides, Portland, Oregon, 134.

Valdez, O., Flores, E., García, J., Chavira, J., Rubio, R., Ortiz, J., 2008. Use of Pleurotus pulmonarius to change the nutritional quality of wheat straw. I. Effect on chemical composition. INCI 33(6): 435-438.

Vilgalys, R., Moncalvo, J., Liou, S., Volovsek, M., 1996. Recent advances in molecular systematics of the genus Pleurotus. In: Royse D. (ed.). Mushroom biology and mushroom products. Penn State University Press, University Park, PA, 91-102.

Wasser, S., 2002. Medicinal mushrooms as a source of antitumor and immunomodulating polysaccharides. Applied Microbiology and Biotechnology, 60: 258-274.

Wojewoda, W., Ławrynowicz, M., 2006. Czerwona lista grzybów wielkoowocnikowych w Polsce. In: Mirek Z., Zarzycki K., Wojewoda W., Szeląg Z. (eds.). Czerwona lista roślin i grzybów Polski, pp. 53-71. Instytut Botaniki im. Szafera PAN, Kraków.

Xu, W., Huang, J., Cheung, P., 2012. Extract of Pleurotus pulmonarius suppresses liver cancer development and progression through inhibition of VEGF induced PI3K/AKT signaling pathway. PLoS One, 7(3): e34406.

Yatsuzuka, R., Nakano, Y., Jiang, S., Ueda, Y., Kishi, Y., Suzuki, Y., Yokota, E., Rahman, A., Ono, R., Kohno, I., Kamei, C., 2007. Effect of usuhiratake (Pleurotus pulmonarius) on sneezing and nasal rubbing in BALB/c mice. Biological and Pharmaceutical Bulletin, 30(8): 1557-1560. 